\title{
Clinical parameters as predictors of bacterial isolation in the uterine content of dogs suspected of pyometra
}

\section{Klinische symptomen als merker van bacteriële isolatie uit de uterus van honden verdacht van pyometra}

\author{
${ }^{1}$ A.M. Kitshoff, ${ }^{1}$ B. van Goethem, ${ }^{2}$ F. Boyen, ${ }^{1,3}$ O. Tas, ${ }^{1}$ I. Polis, ${ }^{1}$ H. de Rooster \\ ${ }^{1}$ Department of Small Animal Medicine and Clinical Biology, Faculty of Veterinary Medicine, \\ Ghent University, Belgium \\ ${ }^{2}$ Department of Pathology, Bacteriology and Poultry Diseases, Faculty of Veterinary Medicine, \\ Ghent University, Belgium \\ ${ }^{3}$ Algemene Dierenkliniek Randstad, Antwerpen, Belgium
}

adriaan.kitshoff@ugent.be

\section{BSTRACT}

In this study, female canines referred with clinical signs consistent with pyometra were prospectively evaluated. Signalment, clinical signs, laboratory findings and surgical findings were compared between dogs with and without bacterial isolation based on aerobic techniques. Patients with positive bacterial isolation were placed in the pyometra group, whereas patients with negative bacterial isolation were grouped as mucometra. A total of 140 dogs (118 with pyometra and 22 with mucometra) met the inclusion criteria.

Prereferral antibiotic administration was associated with a prolonged duration of clinical signs in the patients of the pyometra group (12 \pm 2 days versus $7 \pm 1$ days; $P=0.006)$. In the pyometra patients, clinical signs, like pyrexia, anorexia and discomfort on abdominal palpation, were observed more commonly than in the mucometra group. The total leukocyte count was the only parameter that differed significantly between the two groups $(\mathrm{P}=0.01)$. Although no difference in color and consistency of the uterine fluid was noted, the uteri of the pyometra group were heavier $(851.80 \pm 800.30 \mathrm{~g}$ compared to $263.50 \pm 297.10 \mathrm{~g})$. $E$. coli was the most commonly isolated bacterium $(\mathbf{9 2 / 1 2 3 )}$.

\section{SAMENVATTING}

In deze studie werden vrouwelijke honden met klinische klachten verenigbaar met pyometra prospectief geëvalueerd. Het signalement, de klinische symptomen, laboratoriumresultaten en chirurgische bevindingen werden vergeleken tussen honden met en zonder bacteriële isolatie op basis van aërobe technieken. Patiënten met een positieve bacteriële isolatie werden in de pyometragroep geklasseerd, terwijl patiënten met een negatieve bacteriële isolatie als honden met mucometra werden gegroepeerd. Honderdveertig honden (118 met pyometra en 22 met mucometra) voldeden aan de inclusiecriteria.

De toediening van een antibioticum vooraleer door te verwijzen was geassocieerd met verlengde klinische symptomen bij de patiënten van de pyometragroep $(12 \pm 2$ dagen versus $7 \pm 1$ dagen; $\mathrm{P}=$ $0,006)$. Bij de pyometrapatiënten werden klinische symptomen, zoals koorts, anorexia en ongemak bij abdominale palpatie vaker waargenomen dan bij de mucometrapatiënten. Het totale aantal leukocyten was de enige parameter die significant verschilde $(\mathrm{P}=0,01)$. Hoewel er tussen de twee groepen geen verschil in kleur en consistentie van de baarmoedervloeistof werd opgemerkt, was de baarmoeder van de honden met pyometra zwaarder dan bij de honden met mucometra $(851,80 \pm 800,30 \mathrm{~g}$ versus $263,50 \pm 297,10 \mathrm{~g})$. E. coli was de vaakst geïsoleerde bacterie $(92 / 123)$.

\section{INTRODUCTION}

Pyometra is defined as a dilatation of the uterus with pus and occurs in about one fourth of the intact female dog population by the age of 10 years (Egenvall et al.,
2001; Smith, 2006; Pretzer, 2008). It is regarded as a chronic disease that manifests acutely about eight to twelve weeks after estrus (Dow, 1959; Pretzer, 2008). Repeated oestrogen stimulation sensitizes the uterus to the effects of progesterone, which leads to cys- 
tic endometrial changes, termed cystic endometrial hyperplasia $(\mathrm{CEH})$. In some dogs with $\mathrm{CEH}$, uterine fluid accumulation develops leading to the formation of mucometra, hematometra or hydrometra. In these cases, the uterus fills with mucoid, bloody or watery secretions, respectively (McAfee and McAfee, 1976), which predisposes the uterus to secondary infections (Dow, 1959; Smith, 2006). Although pyometra is often preceded by the development of $\mathrm{CEH}$, these two conditions may occur independently (De Bosschere et al., 2001). Bacteria likely gain entrance to the uterus prior to diestrus when the cervix is open (Tsumagari et al., 2005, Pretzer, 2008). Uterine changes related to $\mathrm{CEH}$ may result in the inability of the uterus to contract and the cervix to relax, decreasing the effectiveness of bacterial clearance (Verstegen et al., 2008). If bacteria are not cleared efficiently before the onset of the luteal phase, pyometra will develop (Pretzer, 2008). The most commonly isolated bacterium in dogs is Escherichia coli (Rubio et al., 2014; Noakes et al., 2001; Allen et al., 1984; Dhaliwal et al., 1998; Fransson et al., 1997; Wheaton et al., 1989; Stone et al., 1988; Sandholm et al., 1975).

Dogs with mucometra, hematometra or hydrometra are mostly asymptomatic, although clinical signs such as abdominal distension and mucoid to watery vaginal discharge can be encountered (Pretzer, 2008; Potter et al., 1991; McAfee and McAfee, 1976). In contrast, clinical signs are consistently present in dogs with pyometra and commonly include abdominal distension, lethargy, polydipsia, polyuria, vomiting, diarrhea and dehydration (Wheaton et al., 1989; Smith, 2006). Other clinical findings, like pyrexia, hypothermia, tachycardia, tachypnea and abnormal mucous membrane color can also be present (Egenvall et al., 2001; Verstegen et al., 2008). Differentiation between these two disease conditions can be of clinical relevance when prioritizing surgeries or in cases where owner finances are of short-term concern.

The aim of this prospective study was to assess whether clinical parameters can be used to differentiate dogs with septic from dogs with aseptic uterine content based on aerobic culture in dogs suspected of pyometra. The signalment, clinical signs, blood values and surgical findings between the two groups were compared.

\section{MATERIALS AND METHODS}

Dogs presented to the Department of Small Animal Medicine and Clinical Biology of Ghent University between May 2006 and June 2011, were prospectively evaluated when suspected of pyometra. Patient selection was based on the presence of a fluid distended uterus on ultrasonography in combination with one of the following clinical signs: anorexia, discomfort on abdominal palpation, pyrexia (body temperature equal to or higher than $39^{\circ} \mathrm{C}$ ), polyuria, polydipsia, vomiting or vaginal discharge. Clinical data were collected preoperatively by using questionnaires completed by the clinician on duty. Data recorded included breed, age, weight and clinical findings (anorexia, discomfort on abdominal palpation, temperature, polyuria/ polydipsia, vomiting and the presence or absence of vaginal discharge).

Preoperative blood analysis was advised in all cases but the availability of a complete blood count and/ or biochemistry results was not a prerequisite to enter this study.

Perioperative findings were recorded on data sheets, but were occasionally inconsistently completed under emergency circumstances. The findings included location and extent of uterine dilatation, uterine wall integrity, presence or absence of free abdominal fluid, weight of the uterus with its contents (uterine weight), color and consistency of the intrauterine fluid. The location of the uterine distension was classified as distension of the uterine body, a single uterine horn or both uterine horns and the extent of uterine dilatation as uniform or ampulla-shaped. The presence of uterine fluid accumulation was confirmed after ovariohysterectomy by an incision into the uterine lumen. The uterine content was sampled aseptically, using a commercialswaband transportmedium (eSwab, Copandiagnostics, Brescia,Italy)foraerobic cultureand antimicrobial susceptibility testing. The intrauterine fluid was further subjectively classified based on color (white, coffee-colored, brown or red) and consistency (watery, creamy or thick creamy). Subsequently, the uterus with its content was weighed and the weight was recorded.

Antimicrobial susceptibility testing was performed according to the disk diffusion method. Manufacturer guidelines (Rosco, Denmark) were followed for the media and conditions related to inoculation and incubation. The growth inhibition zone diameters were measured manually. The criteria for interpretation of resistance were based on clinical breakpoints as described by the Clinical and Laboratory Standards Institute's 'Performance standards for antimicrobial disk and dilution susceptibility tests for bacteria isolated from animals' (Watts et al., 2008). If the criteria were not available in these documents, the manufacturers criteria were used.

For the purpose of this study, all patients without bacteria isolated during the aerobic culture of the uterine content were classified as mucometra and all patients with positive bacterial cultures were regarded as pyometra cases. Patients with mucometra, hematometra and hydrometra were all included in the mucometra group. Data were collated into a spreadsheet program and compared between the pyometra group and the mucometra/hydrometra group. Descriptive statistics were performed using commercial SPSS software (IBM, New York, USA). Continuous variables were tested for normality using the Kolmogorov-Smirnov test. The comparison of quantitative data with outcomes pyometra and mucometra were evaluated with the independent samples t-test 
or the Mann-Whitney rank sum test depending on the sample normality. When the independent sample t-test was used, the Levene's test was employed additionally to determine the equality of variance. Qualitative variables were compared between the two groups using the Fisher's exact test. This test was also used to compare the prevalence of dog breeds presented with pyometra or mucometra, with the prevalence of breeds in the at-risk hospital population.

Quantitative data within the pyometra and the mucometra groups were compared with qualitative data that had only two outcomes, using the independent samples t-test.

Data was presented as mean \pm standard deviation and the significance was set at $\mathrm{P}<0.05$.

\section{RESULTS}

A total of 140 patients were included in the study. Bacteria were isolated from the uterine content in 118 patients (pyometra), whereas in 22 dogs, no bacteria were isolated (mucometra).

\section{Signalment}

The prevalence of pyometra or mucometra in breeds that were presented more than five times is depicted in Figure 1. When compared to the at-risk hospital population (intact female dogs), the prevalence of pyometra $(0.6 \%)$ was 60 times higher than that of mucometra $(0.01 \%)$. Golden retrievers $(\mathrm{P}=0.001)$, American Staffordshire terriers $(\mathrm{P}=0.002)$, Weimaraners $(\mathrm{P}=0.004)$, and Rottweilers $(\mathrm{P}=0.038)$ had a significantly higher prevalence of pyometra than the at-risk hospital population of the same breed.

The mean age of the dogs with pyometra was 98 \pm 32 months (range 16-168 months) and the mean weight was $25.20 \pm 15.40 \mathrm{~kg}$ (range $1.80-89.00 \mathrm{~kg}$ ). The patients with mucometra had a mean age of 84 \pm 42 months (range 13-159 months) and their mean weight was $18.40 \pm 19.60 \mathrm{~kg}$ (range $2.00-79.00 \mathrm{~kg}$ ).

The mean duration of clinical signs in the dogs diagnosed with pyometra was $9 \pm 9$ days (range 1-60 days) compared to $13 \pm 11$ days (range 1-42 days) for the mucometra cases.

No statistical differences were found between the age at presentation, body weight, or the mean duration of clinical signs between the pyometra and mucometra patients, although there was a tendency of the patients of the latter group to be younger $(\mathrm{P}=0.08)$ and to weigh less $(\mathrm{P}=0.07)$.

\section{Anamnesis}

The history of the patients indicated that most patients (pyometra 64/118; mucometra 11/22) had not yet received antibiotics before presentation. If however, an antibiotic had been administered, the type was mostly not known to the owner and was thus inconsistently recorded. Antimicrobial treatment prior to referral in patients with pyometra was associated with

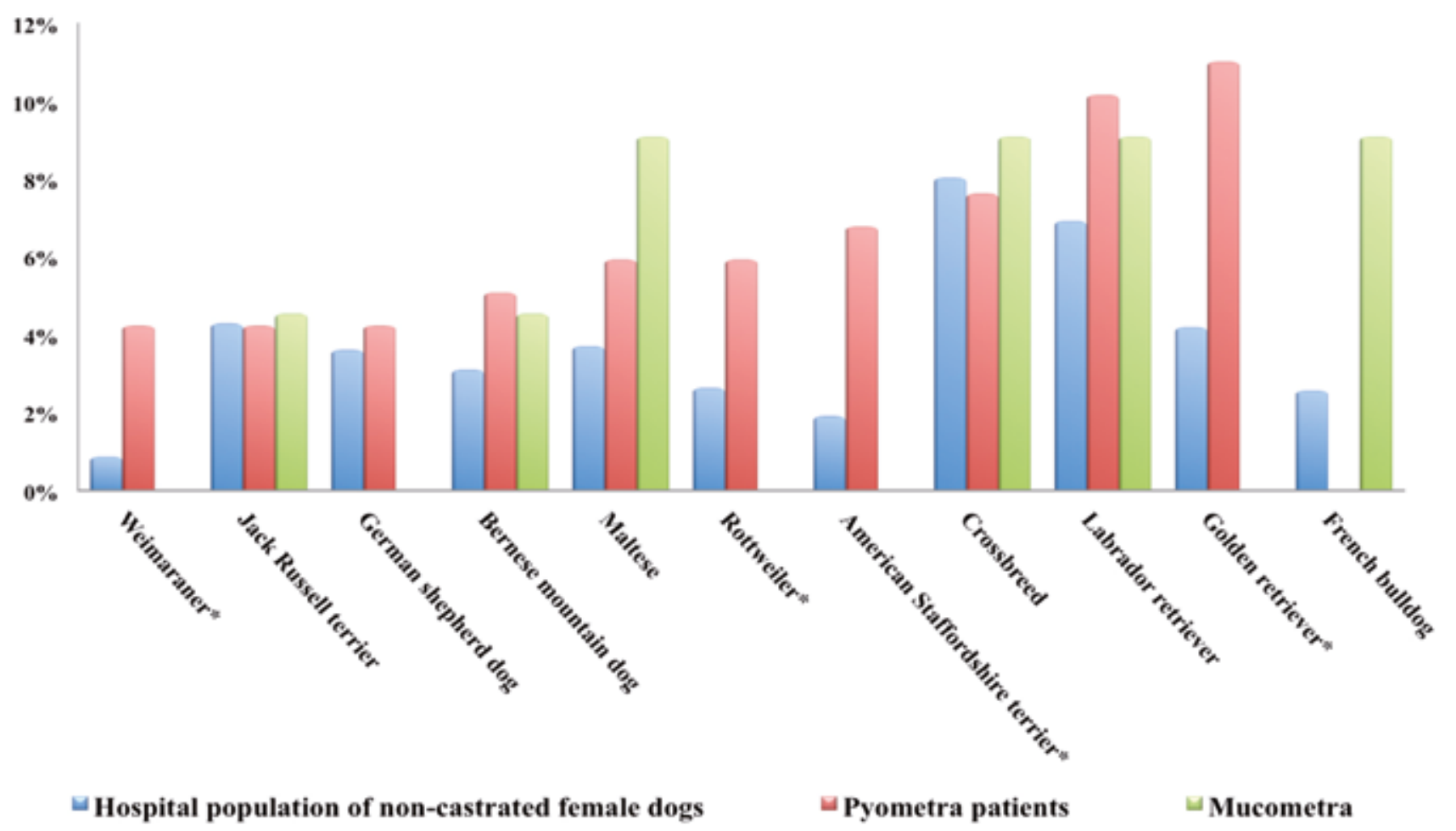

Figure 1. Diagram reflecting the prevalence of the most commonly presented breeds with pyometra and mucometra, compared to the prevalence of the at-risk hospital population during the study period. The prevalence of breeds marked with an asterisk $(*)$ is significantly higher than expected. 
a prolonged duration of clinical signs when compared to no treatment $(12 \pm 2$ days and $7 \pm 1$ days, respectively; $\mathrm{P}=0.006$ ). A minority of the patients (pyometra 7/118; mucometra 2/22) had a history of anticonception therapy but the drug name and duration and/or frequency of administration were unknown to the owners in most instances.

\section{Clinical, laboratory and surgical findings}

The prevalence of the most relevant clinical symptoms and the blood results are summarized in Table 1. Pyrexia at clinical presentation was more commonly seen in the pyometra patients $(61 / 118)$ than in the mucometra patients $(3 / 22)(\mathrm{P}=0.001)$. $\mathrm{Pa}-$ tients that had received antimicrobial agents at home before referral had a lower body temperature than patients that had not been treated with antimicrobial agents $\left(39.16 \pm 0.67{ }^{\circ} \mathrm{C}\right.$ and $38.75 \pm 1.20^{\circ} \mathrm{C}$, respectively; $\mathrm{P}=0.02)$. Compared to mucometra, pyometra was more often associated with anorexia (93/118 versus $13 / 22 ; \mathrm{P}<0.05)$ and discomfort on abdominal palpation $(51 / 118$ versus $3 / 22 \mathrm{P}=0.006)$. Most patients presented with an open-cervix pyometra (73/118). Vaginal discharge was also observed in 13/22 dogs of the mucometra group.
The total leukocyte count was the only blood parameter that differed significantly when compared between the two groups $(\mathrm{P}=0.01)$. The mean value for the dogs with pyometra was $26.97 \pm 22.72 \times 10^{9} / \mathrm{L}$ and with mucometra $10.72 \pm 5.99 \times 10^{9} / \mathrm{L}$ (reference 5.05-16.76 x 109/L). There was a significant difference in the pyometra group, when hematocrit and ALP levels were compared between vomiting (41.92 $\pm 7.94 \%$ and $338.97 \pm 368.98 \mathrm{U} / \mathrm{L})$ and non-vomiting dogs $(37.75 \pm 9.37 \%$ and $191.43 \pm 121.06 \mathrm{U} / \mathrm{L}$; $\mathrm{P}=0.04$ and $\mathrm{P}=0.03$, respectively). Additionally, the dogs with pyometra that presented with polyuria/ polydipsia, were significantly older (102.90 \pm 30.65 days) than the patients that did not have polyuria/ polydipsia $(85.69 \pm 31.74$ days; $\mathrm{P}=0.01)$. Patients that presented with mucometra, had higher blood glucose levels when no anorexia was present $(6.21 \pm 0.0 .95$ $\mathrm{mmol} / \mathrm{L})$ than when they were anorexic $(4.77 \pm 0.53$ $\mathrm{mmol} / \mathrm{L})(\mathrm{P}=0.004)$.

Surgical findings indicated that the dilatation of the uterus mostly involved both uterine horns (pyometra 114/118; mucometra 21/22). Dilatation of the body of the uterus (pyometra: 2/118; mucometra: $0 / 22$ ) or of only one horn (pyometra $2 / 118$; mucometra $1 / 22$ ) was less common. Distension of the uterus was uniform in $79 / 118$ and $19 / 22$ of the pyometra and mucometra cases, respectively. In the rest of the study population,

Table 1. The most commonly encountered clinical signs and blood parameters in the dogs presented with pyometra and mucometra. The asterisk $(*)$ indicates statistical significance.

\begin{tabular}{|c|c|c|c|c|}
\hline \multicolumn{5}{|c|}{ Clinical signs } \\
\hline & \multicolumn{2}{|c|}{ Pyometra } & \multicolumn{2}{|c|}{ Mucometra } \\
\hline Abdominal discomfort* & $51 / 118$ & $43.2 \%$ & $3 / 22$ & $13.6 \%$ \\
\hline Anorexia* & $93 / 118$ & $78.8 \%$ & $13 / 22$ & $59.1 \%$ \\
\hline Pyrexia* & $61 / 118$ & $51.7 \%$ & $3 / 22$ & $13.6 \%$ \\
\hline \multicolumn{5}{|l|}{ Mucous membrane color } \\
\hline Pale & $8 / 118$ & $6.8 \%$ & $2 / 22$ & $9.1 \%$ \\
\hline Hyperemic & $4 / 118$ & $3.4 \%$ & $0 / 22$ & $0.0 \%$ \\
\hline Polyuria/polydipsia & $82 / 118$ & $69.5 \%$ & $11 / 22$ & $50.0 \%$ \\
\hline Vaginal discharge & $73 / 118$ & $61.9 \%$ & $13 / 22$ & $59.1 \%$ \\
\hline Vomiting & $45 / 118$ & $38.1 \%$ & $9 / 22$ & $40.9 \%$ \\
\hline \multicolumn{5}{|c|}{ Blood results } \\
\hline & \multicolumn{2}{|c|}{ Pyometra } & \multicolumn{2}{|c|}{ Mucometra } \\
\hline Leukopenia & $3 / 78$ & $3.8 \%$ & $1 / 14$ & $7.1 \%$ \\
\hline Leukocytosis* & $55 / 78$ & $70.5 \%$ & $2 / 14$ & $14.3 \%$ \\
\hline Decreased hematocrit & $33 / 81$ & $40.7 \%$ & $2 / 14$ & $14.3 \%$ \\
\hline Increased hematocrit & $1 / 81$ & $1.2 \%$ & $0 / 14$ & $0.0 \%$ \\
\hline Thrombocytopenia & $5 / 77$ & $6.5 \%$ & $1 / 13$ & $7.7 \%$ \\
\hline Thrombocytosis & $8 / 77$ & $10.4 \%$ & $5 / 13$ & $38.5 \%$ \\
\hline Elevated alkaline phosphatase & $25 / 68$ & $36.8 \%$ & $2 / 13$ & $15.4 \%$ \\
\hline Elevated blood urea nitrogen & $2 / 79$ & $2.5 \%$ & $1 / 14$ & $7.1 \%$ \\
\hline Elevated creatinine & $12 / 75$ & $16.0 \%$ & $1 / 15$ & $6.7 \%$ \\
\hline Hypoglycemia & $6 / 67$ & $9.0 \%$ & $0 / 14$ & $0.0 \%$ \\
\hline Hyperglycemia & $1 / 67$ & $1.5 \%$ & $0 / 14$ & $0.0 \%$ \\
\hline Hyperproteinemia & $3 / 74$ & $4.1 \%$ & $1 / 12$ & $8.3 \%$ \\
\hline
\end{tabular}


Table 2. The culture and susceptibility testing results of the uterine content cultures in the dogs with pyometra ( $S=$ susceptible; $I=$ intermediate susceptibility; $R=$ resistant, $N T=$ not tested).

\begin{tabular}{|c|c|c|c|c|c|c|c|c|c|c|c|c|c|c|c|c|c|}
\hline & & \multicolumn{4}{|c|}{ Amoxicillin } & \multicolumn{4}{|c|}{$\begin{array}{l}\text { Amoxicillin } \\
\text { clavulanic acid }\end{array}$} & \multicolumn{4}{|c|}{ Cephalosporin } & \multicolumn{4}{|c|}{ Ceftiofur } \\
\hline & & $\mathrm{S}$ & I & $\mathrm{R}$ & NT & $\mathrm{S}$ & I & $\mathrm{R}$ & NT & $\mathrm{S}$ & I & $\mathrm{R}$ & NT & $\mathrm{S}$ & I & $\mathrm{R}$ & NT \\
\hline Coryneforme spp. & $n=3$ & 2 & 0 & 1 & 0 & 3 & 0 & 0 & 0 & 2 & 0 & 0 & 1 & 3 & 0 & 0 & 0 \\
\hline E. coli & $n=92$ & 63 & 0 & 29 & 0 & 89 & 0 & 3 & 0 & 17 & 2 & 0 & 73 & 86 & 1 & 3 & 2 \\
\hline Enterobacter spp. & $n=5$ & 1 & 0 & 4 & 0 & 3 & 1 & 1 & 0 & 0 & 0 & 0 & 5 & 4 & 1 & 0 & 0 \\
\hline Enterococcus spp. & $n=4$ & 2 & 0 & 2 & 0 & 4 & 0 & 0 & 0 & 0 & 0 & 1 & 3 & 0 & 0 & 3 & 1 \\
\hline Klebsiella spp. & $n=5$ & 1 & 0 & 4 & 0 & 5 & 0 & 0 & 0 & 0 & 1 & 0 & 4 & 3 & 1 & 0 & 1 \\
\hline Unknown gram-negative & $n=1$ & 0 & 0 & 1 & 0 & 1 & 0 & 0 & 0 & 0 & 0 & 0 & 1 & 1 & 0 & 0 & 0 \\
\hline Unknown gram-positive & $n=1$ & 0 & 0 & 1 & 0 & 0 & 0 & 1 & 0 & 0 & 0 & 1 & 0 & 0 & 0 & 1 & 0 \\
\hline Proteus spp. & $n=1$ & 0 & 0 & 1 & 0 & 1 & 0 & 0 & 0 & 0 & 0 & 0 & 1 & 0 & 0 & 1 & 0 \\
\hline Pseudomonas spp. & $n=2$ & 0 & 0 & 2 & 0 & 0 & 0 & 2 & 0 & 0 & 0 & 0 & 2 & 0 & 1 & 1 & 0 \\
\hline Staphylococcus spp. & $n=3$ & 1 & 0 & 1 & 1 & 2 & 0 & 1 & 0 & 0 & 0 & 0 & 3 & 3 & 0 & 0 & 0 \\
\hline Streptococcus spp. & $n=6$ & 5 & 0 & 1 & 0 & 6 & 0 & 0 & 0 & 2 & 0 & 0 & 4 & 6 & 0 & 0 & 0 \\
\hline
\end{tabular}

the dilatation was 'ampulla-like' in shape. During surgery, a macroscopically visible tear in the wall of the uterine horn was identified in 7 cases. Swabs for culture were taken from the peritoneal cavity of the dogs $(\mathrm{n}=12)$ with free abdominal fluid and were bacteriologically positive in all cases. All of these dogs had concurrent positive isolates of the same bacteria from the intrauterine content.

The mean weight of the uterus was $851.80 \pm$ $800.30 \mathrm{~g}$ (range $50.00-4500.00 \mathrm{~g}$ ) in the pyometra cases and $263.50 \pm 297.10 \mathrm{~g}$ (range $30.00-1280.00$ $\mathrm{g})$ in the mucometra cases $(\mathrm{P}<0.0001)$. The color and consistency of the uterine content and uterine weight in mucometra and pyometra cases did not differ significantly, nor was it associated with preoperative antibiotic administration.

In 108 patients, only one bacterial isolate was obtained. In 6 patients, 2 isolates and in 1 patient 3 isolates were cultured, whereas in another $3 \mathrm{dogs}$, the results were considered polybacterial ( $>3$ bacteria). In all of the patients, in which more than one bacterium was cultured, E. coli was always a component of the combination. In patients with polybacterial cultures, no attempt was made to isolate the species of bacteria with the exception of $E$. coli due to cost limitations.

Excluding the samples of the 3 patients with polybacterial cultures, a total of 123 bacterial isolates were identified. The bacteria cultured included: $E$. coli $(73.2 \%)$, Enterobacter spp. (5.7\%), Streptococcus spp. (4.9\%), Klebsiella spp. (4.1\%), Enterococcus spp. (3.3\%), Staphylococcus spp. (2.4\%), Actinomycetaceae spp. (2.4\%), Pseudomonas spp. (1.6\%), unidentified gram-negative $(0.8 \%)$, unidentified grampositive $(0.8 \%)$ and Proteus spp. $(0.8 \%)$. The results of culture and susceptibility testing were available for all of these bacteria except for $1 E$. coli isolate and 2 Enterobacter spp isolates (Table 2). In patients with only 1 isolate, the type of bacterium was not associated with clinical signs, blood values, uterine weight, color or consistency of the intrauterine fluid. In addition, no association was found between the number of bacterial species cultured per patient and uterine weight, color of the intrauterine fluid or consistency of the uterine fluid.

\section{DISCUSSION}

Repeated estrous cycling in dogs results in stimulation of the uterus by oestrogen, which makes the endometrium more responsive to progesterone (Smith, 2006). Progesterone induces uterine glandular secretion, endometrial proliferation, decreased myometrium contractility and leads to leukocyte inhibition (Smith, 2006; Bowen et al., 1985). The uterine responses to these ovarian hormones are interrelated and cumulative and lead to the development of $\mathrm{CEH}$ (De Cock et al., 1997). Dilatation of the uterus due to sterile content can occur secondarily to $\mathrm{CEH}$ and is classified based on the consistency and composition of the fluid into mucometra, hematometra or hydrometra (De Bosschere et al., 2001). In most instances, the intrauterine environment becomes favorable for bacterial growth, predisposing the uterus to secondary infection (Pretzer, 2008; Dow, 1959). Bacterial contamination is believed to occur by opportunistic fecal bacteria, prior to diestrus, when the cervix is still open (Pretzer, 2008; Tsumagari et al., 2005).

Pyometra is regarded as one of the most common urogenital disorders in intact female dogs (Ortega-Pacheco et al., 2012). Nevertheless, even after decades of research, the true etiopathogenesis of pyometra is still not fully understood (De Bosschere et al., 2001; Sandholm et al., 1975; Dow, 1959). In the literature, there is still controversy on whether or not the definition of pyometra should include the presence of bacteria in association with the presence of uterine pus (Pretzer, 2008; Dow, 1959), although pyometra is most commonly used to address only infected accumulation. Patients with pyometra are classically middle-aged to old (Gibson et al., 2013; Hagman et al., 2011; Egenvall et al., 2001; Niskanen and Thrus- 
field, 1998; Wheaton et al., 1989; Dow, 1959) but dogs as young as six months of age can also be affected (Stone et al., 1988). The prevalence of pyometra in some breeds is higher than in others (Gibson et al., 2013; Smith, 2006) and differs according to the country of the study due to the regional popularity of specific breeds.

In the current study, only Golden retrievers, American Staffordshire terriers, Weimaraners and Rottweilers had a significantly higher prevalence. Of these dog breeds, Golden retrievers and Rottweilers have been previously reported to have a higher prevalence (Gibson et al., 2013; Smith, 2006; Egenvall et al., 2001; Niskanen and Thrusfield, 1998; Krook et al., 1960).

In this study, antibiotics had been administered to $50 \%$ of the mucometra cases before presentation, which might have resulted in some of the pyometra cases (developing or already established) incorrectly classified as mucometra because of negative bacteriology results. However, there is ample clinical evidence that suggests that antibacterial therapy alone cannot adequately control infection in pyometra cases (Verstegen et al., 2008), making it unlikely that shortterm treatment would efficiently suppress in vitro growth. Furthermore, about $45 \%$ of the positively tested pyometra cases also received antibiotics before presentation. Previous studies have also documented negative bacterial cultures in $8.9-26 \%$ of dogs with suspected pyometra (Bigliardi et al., 2004; Dhaliwal et al., 1998; Wadås et al., 1996). It is believed that, in addition to preoperative antibiotic administration, the local immune system can kill bacteria leading to negative bacterial cultures (Dhaliwal et al., 1998). Previous studies have indicated that only $2 \%$ of histopathologically confirmed pyometra cases have negative isolations using aerobic and anaerobic techniques (Fransson et al., 1997). In this study, a number of 'negative' cultured samples contained anaerobic organisms rather than being truly sterile. However, only limited positive anaerobic cultures from pyometra in bitches have been documented (Dow et al., 1986; Berg et al., 1979; Osbaldiston, 1978). For this reason and due to financial constraints, no anaerobic isolation was performed.

According to the literature, mucometra, hematometra and hydrometra do not commonly result in obvious clinical signs (Pretzer, 2008; McAfee and McAfee; 1976; Dow, 1959), whereas pyometra always leads to signs of systemic illness (Pretzer, 2008; De Bosschere et al., 2002), such as anorexia, depression, vomiting, diarrhea, polydipsia, polyuria, pyrexia and dehydration (Smith, 2006; Wheaton et al., 1989). The results from the present study do not completely support this distinction since an equal percentage of dogs in both clinical groups were presented with symptoms, such as polyuria/polydipsia, vaginal discharge or vomiting. Hence, systemic clinical signs in combination with vaginal discharge do not suffice to make a definite diagnosis of pyometra in dogs (Fransson et al., 1997). Only the incidence of anorexia, py- rexia and discomfort on abdominal palpation were statistically different between the dogs of the pyometra and the mucometra groups.

Open-cervix pyometra is suspected in dogs with vaginal discharge (Smith, 2006), but other potential causes include metritis, vaginitis, estrus and immune mediated thrombocytopenia (Troxel et al., 2002; Nelson and Feldman, 1986). To the authors' knowledge, discharge from the vagina is not a commonly reported clinical sign in mucometra cases. Fransson et al. 2004 reported discharge in 6 out of 9 cases with histopathologically confirmed CEH. Unfortunately, no bacterial culture results were available for this group of dogs (Fransson et al., 2004). In the current study, the same prevalence of vaginal discharge in bitches with mucometra as in those with pyometra was demonstrated. A distinction between pyometra and mucometra based purely on the visual examination of vaginal discharge may be inaccurate (Hagman et al., 2006; De Bosschere et al., 2001). In the current study, these observations were confirmed by finding no significant differences in color or consistency of the uterine content between the dogs with pyometra and those with mucometra.

Comparison of the pyometra and mucometra cases identified leukocytosis as the only parameter of the blood analysis that was significantly different. On the other hand, the present study failed to show any association between closed- or open-cervix pyometra and any of the blood parameters. In a previous report however, leukocytosis is suggested to be more pronounced in closed-cervix pyometra than in open-cervix pyometra (Gupta and Dhami, 2013).

There was no statistical difference in the weight of the uterus when compared to cervical patency in the current study; this is in contrast to a previous report (Dow, 1959). All patients with vaginal discharge were classified as having an open cervix but no attempt was made to measure the degree of cervical patency. The degree of opening of the cervix might have played a role in the extent of uterine filling and hence the weight of the uterus with its content.

This study shows that the presence of free abdominal fluid in combination with uterine distension with fluid may be indicative of septic peritonitis. The authors advise sampling any free abdominal fluid for culture and antimicrobial susceptibility testing. All patients with free abdominal fluid had concurrent positive bacterial cultures of the uterine content. The presence of free abdominal fluid in combination with uterine distension with fluid can potentially be used for ultrasonographic differentiation between pyometra and mucometra, hydrometra or hematometra.

Multiple veterinary studies have also shown that $E$. coli is the most commonly isolated bacterium in dogs with pyometra (Rubio et al., 2014; Dhaliwal et al., 1998; Fransson et al., 1997; Wheaton et al., 1989; Stone et al., 1988; Allen et al., 1984; Sandholm et al., $1975)$. Since $E$. coli is a member of the normal intestinal flora, this might explain its predominance (Hagman and Kühn, 2002; Wadås et al., 1996). Progesterone-primed uterine endometrium has an affinity for $E$. 
coli, which may be an important pathogenic mechanism enhancing colonization of the uterus (Verstegen et al., 2008; Nelson and Feldman, 1986; Sandholm et al., 1975). In addition, colonization by $E$. coli is enhanced due to the presence of receptors in the endometrium and myometrium (Sandholm et al., 1975).

Normal commensal vaginal bacteria are believed to ascend into the uterus during dietrus (Pretzer, 2008; Tsumagari et al., 2005; Noakes et al., 2001) and to result in disease through toxin production or the release of inflammatory mediators (Noakes et al., 2001). The results of the present study indicate that there might be an interaction between $E$. coli and other bacteria in the pathogenesis of the disease, because if more than one bacterium was cultured, E. coli was always a component.

Amoxicillin and clavulanic acid or fluroquinolones are good initial choices for dogs presenting with pyometra and should be continued at least up to 7-10 days after surgical treatment (Bassessaar et al., 2013; Verstegen et al., 2008; Bartoskova et al., 2007; Yates, 1996). Perioperative and postoperative antibiotic treatment is advised due to alterations in the immune system (Faldyna et al., 2001), the high incidence of concurrent cystitis (Sandholm et al., 1975) and the potential for peritonitis due to uterine rupture, bacterial translocation through the uterine wall and bacterial contamination of the ovarian bursa (Rubio et al., 2014; Van Israel et al., 2002). In vitro susceptibility testing revealed that $92.7 \%$ of all the cultured bacteria were sensitive to amoxicillin-clavulanic acid, the antibiotic of choice administered to pyometra-suspected dogs in the authors' institution (Maddens et al., 2010). It should be noted that by the time the bacteriological results became available, most pyometra cases had already been fully recovered, and no antibiotic regimen changes had been instilled if in vitro resistance was reported. All cases reported here survived to discharge. Despite the incorrect regime in some of the patients of the present study, the successful outcome could be related to differences between in vitro and in vivo sensitivity of bacteria to antibiotics. Fast improvement of immunological parameters is seen in patients that have undergone hysterectomy (Bartoskova et al., 2007). It is the authors' opinion that removal of the diseased tissue in patients receiving incorrect antibiotics likely results in a low enough bacterial and endotoxin load, with which the recovering immune system was able to cope.

Complete ovariohysterectomy still remains the treatment of choice for any bitch presenting with pyometra, and is the only treatment that -if conducted properly- excludes the risk of recurrence (Verstegen et al., 2008). Antibiotic treatment alone is never a sound treatment choice as at best, a delay in worsening of clinical signs is seen, hence requiring additional therapy at a later stage (Verstegen et al., 2008). This delay in worsening of clinical signs was observed in this study population. The delay in presentation of the dogs for treatment was likely due to failure of treatment, owner reluctance to treat or deterioration of the clinical signs. Although not specifically assessed, it is also possible that some dogs might not have been presented for surgical treatment due to resolution of the clinical signs. Medical treatment options in dogs with pyometra involve the combination of antibiotics and either repeated prostaglandin F2 $\alpha$ or progesteronereceptor antagonists resulting in cervical relaxation (Johnston et al., 2001) or a combination of dopamine agonists and progesterone receptor antagonists (Gobello, 2006). Medical treatment without surgical intervention should preferentially only be attempted in young breeding bitches with normal organ function (Verstegen et al., 2008; Smith, 2006).

Limitations of the current study include the selection of patients based on clinical signs, that might have favored the selection of patients with sterile uterine content in association with clinical signs. Therefore the results obtained do not necessarily give a true reflection of the whole dog population. Other limitations were the absence of intraoperative cytology of the uterine content and histopathological analysis of the uterine wall that might have had further helped to differentiate true mucometra cases from dogs with pyometra, in which no bacteria were cultured in vitro.

The results of the current study indicate that dogs with fluid-filled uteri with negative bacterial cultures may present with clinical signs similar to those observed in dogs with positive cultures. Patients with clinical signs of anorexia, pyrexia and discomfort on abdominal palpation or with free abdominal fluid are more likely to have a positive bacterial isolation based on aerobic culture techniques. Color and consistency of the uterine content are unreliable factors to differentiate between patients with septic and patient with aseptic uterine content. Amoxicillin clavulanic acid is a good first-line antimicrobial for the supportive treatment of pyometra in dogs.

\section{REFERENCES}

Allen W.E., Noakes D.E., Renton J.P. (1984). The genital system. In: Chandler E.A., Sutton J.B., Thompson D.J. (editors). Canine Medicine and Therapeutics. Oxford, Blackwell scientific publications, p. 442-462.

Bartoskova A., Vitasek R., Leva L., Faldyna M. (2007). Hysterectomy leads to fast improvement of haematological and immunological parameters in bitches with pyometra. Journal of Small Animal Practice 48, 564-568.

Bassessaar V., Verma Y., Swamy M. (2013). Antibiogram of bacterial species isolated from canine pyometra.Veterinary World 6, 546-549.

Berg J.N., Fales W.H., Scanlan C.M. (1979). Occurrence of anaerobic bacteria in diseases of the dog and cat. Journal of the American Animal Hospital Association 40, 876881.

Bigliardi E., Parmigiani E., Cavirani S., Luppi A., Bonati L., Corradi A. (2004). Ultrasonography and cystic hyperplasia-pyometra complex in the bitch. Reproduction of Domestic Animals 39, 136-140.

Bowen R.A., Olson P.N., Behrendt M.D., Wheeler S.L., Husted P.W., Nett T.M. (1985). Efficacy and toxicity of 
estrogens commonly used to terminate canine pregnancy. Journal of the American Veterinary Medical Association 186, 783-788.

De Bosschere H., Ducatelle R., Vermeirsch H., Simoens P., Coryn M. (2002). Estrogen- $\alpha$ and progesterone receptor expression in cystic endometrial hyperplasia and pyometra in the bitch. Animal Reproduction Science 70, 251259.

De Bosschere H., Ducatelle R., Vermeirsch H., Van Den Broeck W., Coryn M. (2001). Cystic endometrial hyperplasia- pyometra complex in the bitch: should the two entities be disconnected? Theriogenology 55, 1509-1519.

De Cock H., Vermeirsch H., Ducatelle R., De Schepper J. (1997). Immunohistochemical analysis of estrogen receptors in cystic-endometritis-pyometra complex in the bitch. Theriogenology 48, 1035-1047.

Dhaliwal G.K., Wray C., Noakes D.E. (1998). Uterine bacterial flora and uterine lesions in bitches with cystic endometrial hyperplasia (pyometra). Veterinary Record 143, 659-661.

Dow C. (1959). The cystic hyperplasia-pyometra complex in the bitch. Journal of Comparative Pathology 69, 237250.

Dow S.W., Jones R.L., Adney W.S. (1986). Anaerobic bacterial infections and response to treatment in dogs and cats: 36 cases (1983-1985). Journal of the American Veterinary Medical Association 189, 930-934.

Egenvall A., Hagman R., Bonnett B.N., Hedhammar A., Olson P., Lagerstedt A.S. (2001) Breed risk of pyometra in insured dogs in Sweden. Journal of Veterinary Internal Medicine 15, 530-538.

Faldyna M., Laznicka A., Toman M. (2001). Immunosuppression in bitches with pyometra. Journal of Small Animal Practice 42, 5-10.

Fransson B., Lagerstedt A.S., Hellmen E., Jonsson P. (1997). Bacteriological findings, blood chemistry profile and plasma endotoxin levels in bitches with pyometra or other uterine diseases. Zentralblatt für Veterinärmedizin A 44, 417-426.

Fransson B.A., Karlstam E., Bergstrom A., Lagerstedt A.S., Park J.S., Evans M.A., Ragle C.A. (2004). C-reactive protein in the differentiation of pyometra from cystic endometrial hyperplasia/mucometra in dogs. Journal of the American Animal Hospital Association 40, 391-399.

Gibson A., Dean R., Yates D., Stavisky J. (2013). A retrospective study of pyometra at five RSPCA hospitals in the UK: 1728 cases from 2006 to 2011. Veterinary Record 173, 396.

Gobello C. (2006). Dopamine agonists, anti-progestins, anti-androgens, long-term-release $\mathrm{GnRH}$ agonists and anti-estrogens in canine reproduction: A review. Theriogenology 66, 1560-1567.

Gupta A.K., Dhami A.J. (2013). Haematological alterations in bitches affected with pyometra. The Indian Journal of Field Veterinarians 9, 1-5.

Hagman R., Kindahl H., Fransson B.A., Bergström A., Holst B.S., Lagerstedt A.S. (2006). Differentiation between pyometra and cystic endometrial hyperplasia/ mucometra in bitches by prostaglandin F2 $\alpha$ metabolite analysis. Theriogenology 66, 198-206.

Hagman R., Kühn I. (2002): Escherichia coli strains isolated from the uterus and urinary bladder of bitches suffering from pyometra: comparison by restriction enzyme digestion and pulsed-field gel electrophoresis. Veterinary Microbiology 84, 143-153.
Hagman R., Lagerstedt A.S., Hedhammar Å., Egenvall A. (2011). A breed-matched case-control study of potential risk-factors for canine pyometra. Theriogenology 75, 1251-1257.

Krook L., Larsson S., Rooney J.R. (1960). The interrelationship of diabetes mellitus, obesity, and pyometra in the dog. American Journal of Veterinary Research 21, 120-127.

Maddens B., Daminet S., Smets P., Meyer E. (2010). Escherichia coli pyometra induces transient glomerular and tubular dysfunction in dogs. Journal of Veterinary Internal Medicine 24, 1263-1270.

McAfee L.T., McAfee J.T. (1976). Hydrometra in a bitch. Modern Veterinary Practice 57, 829.

Nelson R.W., Feldman E.C. (1986). Pyometra. Veterinary Clinics North America Small Animal Practice 16, 561576.

Niskanen M., Thrusfield M.V. (1998). Associations between age, parity, hormonal therapy and breed, and pyometra in Finnish dogs. Veterinary Record 143, 493-498.

Noakes D.E., Dhaliwal G.K., England G.C. (2001). Cystic endometrial hyperplasia/pyometra in dogs: a review of the causes and pathogenesis. Journal of Reproduction and Fertility 57, 395-406.

Ortega-Pacheco A., Gutiérrez-Blanco E., Jiménez-Coello M. (2012). Common lesions in the female reproductive tract of dogs and cats. Veterinary Clinics North America Small Animal Practice 42, 547-559.

Osbaldiston G.W. (1978) Bacteriological studies of reproductive disorders of bitches. Journal of the American Animal Hospital Association 14, 363.

Potter K., Hancock D.H., Gallina A.M. (1991). Clinical and pathologic features of endometrial hyperplasia, pyometra, and endometritis in cats: 79 cases (1980-1985). Journal of the American Veterinary Medical Association $198,1427-1431$.

Pretzer S.D. (2008). Clinical presentation of canine pyometra and mucometra: A review. Theriogenology 70, 359363.

Rubio A., Boyen F., Tas O., Kitshoff A., Polis I., Van Goethem B., de Rooster H. (2014). Bacterial colonization of the ovarian bursa in dogs with clinically suspected pyometra an controls. Theriogenology 82, 966-971.

Sandholm M., Vasenius H., Kivistö A.K. (1975). Pathogenesis of canine pyometra. Journal of the American Veterinary Medical Association 167, 1006-1010.

Johnston S.D., Root Kustritz M.V., Olson P.N.S. (2001). Disorders of the canine uterus. In: Johnston S.D., Root Kustritz M.V., Olson P.N.S. (editors). Canine and Feline Theriogenology. WB Saunders, Philadelphia, pp. 206224.

Smith F.O. (2006). Canine pyometra. Theriogenology 66, 610-612.

Stone E.A., Littman M.P., Robertson J.L., Bovée K.C. (1988). Renal dysfunction in dogs with pyometra. Journal of the American Veterinary Medical Association 193, 457-464.

Troxel M.T., Cornetta A.M., Pastor K.F., Hartzband L.E., Besancon M.F. (2002). Severe hematometra in a dog with cystic endometrial hyperplasia/pyometra complex. Journal of the American Animal Hospital Association 38, 85-89.

Tsumagari S., Ishinazaka T., Kamata H., Ohba S., Tanaka S., Ishii M., Memon M.A. (2005). Induction of canine pyometra by inoculation of Escherichia coli into the uter- 
us and its relationship to reproductive features. Animal Reproduction Science 87, 301-308.

Van Israel N., Kirby B.M., Munro E.A. (2002). Septic peritonitis secondary to unilateral pyometra and ovarian bursal abscessation in a dog. Journal Small Animal Practice $43,452-455$.

Verstegen J., Dhaliwal G., Verstegen-Onclin K. (2008). Mucometra, cystic endometrial hyperplasia, and pyometra in the bitch: Advances in treatment and assessment of future reproductive success. Theriogenology 70, 364374.

Wadås B., Kühn I., Lagerstedt A.S., Jonsson P. (1996). Biochemical phenotypes of Escherichia coli in dogs: Comparison of isolates isolated from bitches suffering from pyometra and urinary tract infection with isolates from faeces of healthy dogs. Veterinary Microbiology 52, 293 300.
Watts J.L., Shryock T.R., Apley M., Bade D.J., Brown S.D., Gray J.T., Heine H., Hunter R.P., Mevius D.J., Papich M.G., Silley P., Zurenko G.E. (2008). Clinical and laboratory standards institute: performance standards for antimicrobial disk and dilution susceptibility tests for bacteria isolated from animals. Approved standard. Third Edition [internet]. 2008 [cited 2014 Jun 5]; 33 (7): [about 99 p.]. Available from: http://www.techstreet.com/products/1577345

Wheaton L.G., Johnson A.L., Parker A.J., Kneller S.K. (1989). Results and complications of surgical treatment of pyometra: a review of 80 cases 25. Journal of the American Animal Hospital association 25, 563-568.

Yates D. (1996). The antimicrobial sensitivity of bacteria isolates fron 30 cases of pyometra in the bitch. Irish Veterinary Journal 49, 709-710.

\section{DOURINE BIJ PAARDEN NA WERELDOORLOG I}

Als vergoeding voor het verlies van talrijke dieren, vooral paarden, opgeëist door de Duitse bezetters tijdens de eerste wereldoorlog, kregen de boeren vanaf 1920 paarden en runderen uit Duitsland toegewezen. Enkele maanden na de dekking begonnen zich verontrustende verschijnselen te manifesteren bij de merries, en wel enkel bij dieren die gedekt waren door rondreizende hengsten die eerder Duitse merries gedekt hadden. De eerste gevallen van dourine deden zich voor onder de paarden van een hengstenhouder uit Vladslo. Vanaf 1921 werden wettelijke maatregelen verplicht om de ziekte te stoppen en uit te roeien. Vooral een serologische test, de complementbindingsreactie van Bordet-Gengou (CBR), bleek erg nuttig om besmette dieren op te sporen. Hieronder geven we letterlijk een uittreksel weer uit een verslag opgemaakt door dierenarts - inspecteur De Jonckheere die een belangrijke rol speelde in dit verhaal.

Dourine in korte woorden, is eene specifieke besmettelijke ziekte, dewelke in natuurlijke omstandigheden alleen peerden en ezels aantast. Zij heeft als oorzaak een woekerdiertje de Trypanosoma equiperdum (...).

De eerste kenteekens der ziekte verschijnen bij voorkeur op de geslachtsdeelen zelfs bij die dieren bij dewelke de besmetting niet langs deze weg geschiedt is. Daarna krijgen de woekerdiertjes ingang in den bloedstroom, gebeurlijk komen er huidplekken, en meerendeels wordt het zenuwstelsel aangetast. De ziekte gaat eenen slependen gang, brengt gewoonlijk totale verlamming der achterdeelen teweeg, tot de uiteindelijke uitkomst de dood. Het valt nochtans niet te betwijfelen dat genezing kan voorkomen.

Deze ziekte draagt verscheidene namen: dourine, koppelziekte (maladie du coït), dekziekte, peerdensyphilis, besmettelijke deklamheid, gelachtsklierziekte, enz. De naam dourine in ons land algemeen gebruikt, is een araabsch woord met beteekenis onzuiver, onkuisch, vuil.

Notities van inspecteur De Jonckheere, destijds werkzaam in de West-Vlaamse frontzone. (Schenking Roland Vandermeersch aan de Museumcollectie Diergeneeskundig Verleden 